\title{
Aboutness and ontology: a modest approach to truthmakers
}

\author{
Arthur Schipper ${ }^{1,2}$ (I)
}

Published online: 28 October 2018

(C) The Author(s) 2018

\begin{abstract}
Truthmaker theory has been used to argue for substantial conclusions about the categorial structure of the world, in particular that states of affairs are needed to play the role of truthmakers. In this paper, I argue that closely considering the role of aboutness in truthmaking, that is considering what truthbearers are about, yields the result that there is no good truthmaker-based reason to think that truthmakers must be states of affairs understood as existing entities, whether complex or simple. First, I introduce an aboutness-based account of truthmaking as a metaphysically modest alternative to the orthodox necessitarian account of truthmaking. Second, I discuss the distinction between states and events that has been made on the basis of linguistic evidence regarding aspectual markers and nominalisation. I argue that the modest approach to truthmaking allows us to accept that there is a real distinction between states and events without requiring that the distinction is ontologically substantial. Specifically, what we are talking about with state-truthbearers really differs from what we are talking about with event-truthbearers, but this difference need not be understood as a difference in kinds of entities. Because of its overall modesty, this is a theoretically virtuous result.
\end{abstract}

Keywords Aboutness - Ontology · States of affairs · Modesty · Truthmakers · Quantifiers · Verb aspect · Nominalisation

Arthur Schipper

schipper.philosophy@gmail.com

1 Department of Philosophy, University of Amsterdam, Oude Turfmarkt 145-147, 1012 GC

Amsterdam, The Netherlands

2 Amsterdam, The Netherlands 


\section{Introduction}

Truthmaker theory has been offered as a ground for the existence of entities such as states of affairs (SOAs, for short), understood as existent things. Armstrong (1997: 113-119), for instance, provides what he calls the "truthmaker argument" for the existence of SOAs. According to him, these are not just objects, properties, and the latter's instantiation in the former, but are thought to be structured complexes of objects, properties, and the properties each instantiated in their objects (ibid.: 115). This is the Russellian view of SOAs, often called Russellian facts (see Armstrong 1997: §8.1). ${ }^{1}$ On an alternative, Wittgensteinian view, they are simple entities out of which objects and properties are abstractions. ${ }^{2}$ The argumentation for SOAs as truthmakers has a general target: with perhaps some exceptions (such as existential truths), many truths require SOAs understood as entities as their truthmakers. Whether or not they are simple or complex is an issue that those who wield the truthmaker-argument need not be committed to, ${ }^{3}$ although for exegetical ease and to be consistent with the main line of thinking as presented by orthodox truthmaker theorists such as Armstrong, I shall talk mainly about SOAs as structured complex entities. ${ }^{4}$ The argument goes as follows. Consider the following simple predication:

T1: The table is black.

\footnotetext{
1 Armstrong clearly holds the Russellian view rather than the alternative Wittgensteinian view (see the next sentence), for he thinks that existential truthbearers such as 'Susan exists' and his own example (2004: 55) 'at least one horse exists' are made true by individual objects, Susan and each individual horse (e.g. Old Rowley). And, for Susan or Old Rowley to be truthmakers themselves, they cannot merely be abstractions of SOAs (see Armstrong 1997: 131 for a discussion of his naturalism). Also, he agrees with Kant that existence is not a property. So, Susan's existence is neither a property nor a SOA. Susan is the truthmaker for 'Susan exists'. See Armstrong (2004: 6).

2 Among Wittgensteinian SOAs, we can make a distinction between atomic and complex SOAs. However, complexity here comes not in the form of an internal structural complexity at a level more fundamental than SOAs, as with Russellian facts. Rather, complex SOAs are built out of atomic SOAs, which are structurally simple, and logical operations, such as conjunction. For contemporary Wittgensteinian SOA-theorists, see Westerhoff (2005: especially §3), who thinks that an ontology where SOAs are basic, which he calls a "factualist" ontology (ibid.: 66), is preferable to what he calls a "thingist" ontology. Against such an account, see Dodd (1999: passim, 2000: 8). See also Barwise and Perry (1983: 50) who seem to accept a Wittgensteinian view, but see (ibid.: 52-53) and Barwise (1989: 225), which suggests a Russellian view. See Textor (2016: §0) for a short, but illuminating, discussion.

${ }^{3}$ However, as we shall see, the arguments against SOAs as truthmakers also apply to this issue, for if there is no good argument for SOAs as truthmakers, then there is no good argument for SOAs understood as either complex or simple entities as truthmakers.

${ }^{4}$ Everything I say about them can be translated into talk about SOAs as simples without loss. But, I do this both so that I stick more closely to Armstrong's argumentation and because unlike the stronger, alternative view, this view bears no commitments to SOAs being fundamental or the only concrete parts of reality. The argumentation in the rest of the paper should apply to both views. Whether SOAs are complex or simple is a discussion concerning what the right story is about the further metaphysical detail we need to give to the right account of SOAs. This issue also foreshadows my argument at the end of $\S 1.1$ for metaphysical modesty, which could also be run with this distinction, instead of the more general distinction between particularised properties (PAPs) and SOAs which I use there.
} 
The existence of the table does not guarantee that $\mathrm{T} 1$ is true, because the table could exist without it being black (say, it wasn't lacquered black but had its natural, brown, wood colour). The existence of blackness is also not enough to guarantee the truth of T1, as there could be blackness (and black things) without the table being black. There must be something that exists that makes true T1 (since it's true). But what is it? Consider, the fact or SOA the table's being black. This is either a structured complex composed of an object (the table) and blackness, or a basic entity out of which the table and blackness are abstractions. If such an entity exists, then the truth of T1 is guaranteed. Since something must make truths such as T1 true and SOAs are the best candidates, truthmaker theorists conclude that SOAs exist. Thus, we have a two-premise argument:

Premise 1 (P1): Truths such as T1 must have at least one truthmaker.

Premise 2 (P2): SOAs, understood as entities, are the best candidates for being the truthmakers for many truths (such as T1).

Conclusion (C1): SOAs exist.

First, we have a premise relying on the truthmaker principle: there must be truthmakers for truths such as T1. Second, we have a premise stating that the best candidate truthmakers for many truths are SOAs; Armstrong writes, "there seems to be no acceptable candidate for a truthmaker for statements that contingently link particulars to universals other than states of affairs" (ibid: 119; emphasis added). Thus, SOAs are taken not only to be the best explanation for these truths, but the only acceptable explanation. The argument to $\mathrm{C} 1$ is clearly (a) an inference to the best explanation which (b) relies on the truthmaker principle (expressed in P1).

This truthmaker-argument, to defend $\mathrm{P} 2$, relies on a substantial assumption about the truthmaking relation. According to this assumption the best possible candidate must be some entity which by its very existence can necessitate the truth of truthbearers such as T1, making T1 true in all possible worlds where T1 and the entity exist, ${ }^{5}$ or more generally,

Necessitation-Truth (NEC): $\forall p \forall w$ (if $p$ is true at $w$ then $\exists x\left(x\right.$ exists at $w \wedge \forall w^{\prime}$ (if $x$ and $p$ exist at $w^{\prime}$ then $p$ is true at $\left.\left.w^{\prime}\right)\right)$ ). ${ }^{6}$

\footnotetext{
5 Merricks calls this "conditional necessitarianism" (2007: 7). This is the most plausible form of necessitarianism, for it doesn't require that truthbearers are necessary entities, that is, that they necessarily exist. There is, however, a stronger metaphysical account which states that "for all $x$ and all $p, x$ is a truthmaker for $p$ only if $x$ 's mere existence is metaphysically sufficient for $p$ 's truth" (Merricks ibid.: 5). Armstrong (2003: 12, 2004: 6, 7), Fine (1982: 69), Fox (1987: 189), Molnar (2000: 84), and Smith (1999: 276) are just a few of the truthmaker theorists who defend and utilise the stronger metaphysical version of NEC. Russell (1985: 96, 97) would reject such a strong metaphysical account based on his views on modality. When I speak of NEC, I speak of the weaker conditional form, as that is strong enough. See also Armstrong (2004: 5).

6 A central part of NEC is that $p$ must be made true by $x$ only on the condition that both $x$ and $p$ exist. One might also try to put NEC in terms of a modal, box operator, without quantification over worlds. However, unless modalism is true (and truthmaker theory has no explicit commitments in this regard), then modal operators can be understood in terms of quantification over worlds. Merricks (2007: Chapters 4, 5) argues extensively that a metaphysically substantial account of truthmaking, either in terms of possible worlds (whether realist or ersatz) or modal operators, is incompatible with the central aim of
} 
The central thought is that anything short of this, that is, a guarantee of $p$ 's truth, for any $p$, on the basis of some $x$ 's existence, does not give a strong enough guarantee of truth. Armstrong explicitly identifies NEC as the central assumption in the truthmakerargument when he explains that "the assumption here is that the truthmaker for truth must necessitate that truth" (2004: 115; emphasis added). If a truthmaker theorist rejects NEC, she would allow that there are worlds in which a truthbearer's truthmaker exists but where the truthbearer is false. Allowing this, a non-necessitarian would have quite a bit of explaining to do to explain why, given this possibility, the table must be ruled out as a truthmaker of T1 'the table is black'. She would have to rule out the following: that in some worlds, the table guarantees T1's truth and, thus, makes it true, while in others it doesn't. NEC ensures that the table is ruled out as a truthmaker-its very existence cannot guarantee the truth of $\mathrm{T} 1$, for there are worlds in which the table exists and T1 is false. NEC gets the SOA-theorist a strong enough guarantee to ensure that SOAs are required as truthmakers for truth. ${ }^{7}$ In this way, accepting NEC introduces into our ontology special entities called SOAs, standardly understood as structured, complex entities, over and above the objects and properties out of which they are composed, which must play the truthmaker-role.

There is something odd about this strategy. The reason why Armstrong thought that SOAs were not only the best candidate truthmakers for certain truths but the only "acceptable candidate" is because of NEC. ${ }^{8}$ But if SOAs are needed as the only entities which can satisfy NEC, the orthodox truthmaker theorist might be begging the question against alternative, possibly better candidates. At best, the argument is an inference to the best explanation, in which an entailment or necessitation of truth by SOAs is taken to be the best explanation of truth.

However, as with every other argument from the best explanation, this one can be rejected if it contravenes theoretical principles or lacks an important theoretical virtue. $^{9}$ Two chief virtues are theoretical modesty and parsimony:

Footnote 6 continued

truthmaker theory: to account for the asymmetric dependence of truths on reality. The non-ontological account which I sketch in the next section and which I argue for throughout has the added benefit of not requiring either quantification over worlds or modal operators. See Forbes (1989) for a general defence of modalism and Bennett's (2011: 194) discussion of the implications of modalism for truthmaker theory, especially with regard to Merricks (2007: Chapters 4, 5).

7 See Armstrong (2004: §8.12), where he argues for this further. There are some truthmaker theorists who reject NEC but who still talk about facts and SOAs as truthmakers. For instance, one may reject necessitation for general issues to do with modality (e.g. Mellor 2003: 214, 215). Such theorists may accept an ontology of SOAs and facts for other reasons than the truthmaker-argument. Mellor argues for facts as the relata of causation (1995: passim). Westerhoff doesn't even mention Armstrong's (1997: 113-119) "truthmaker argument" at all, and instead distinguishes between two types of arguments for a SOA-based ontology, which he calls the "semantic" (2005: 72-77) and "cognitional" (ibid.: 66) arguments. Discussion of these would take us too far off topic. See Dodd (1999, 2000) for criticisms. Another argument is that facts promise to give a solution to the problem of instantiation (Armstrong 1997: 115; Hossack 2007: 33). But, see Dodd (2009: 331, 332) for extensive criticism.

8 See also Armstrong (2004: 48f).

9 See Paul (2012: 22) who takes such theoretical virtues as simplicity to be as truth conducive in metaphysical theorizing as in scientific theorizing. There are others who disagree; see Huemer (2009), Kriegel (2013), and Willard (2014). 
Modesty: that one should not take one's theory to explain more (i.e. overestimation) or less (underestimation) than it can.

The former contravention, that is, overestimation, is the most standard interpretation of modesty as a theoretical virtue. One is clearly immodest if one overestimates one's abilities, in this case one's explanatory or theoretical power. But, the latter contravention (underestimation) is just as important: not accepting or admitting that one's theory can explain as much as it can would be a display of false modesty. And

Parsimony: that one should not postulate entities beyond necessity.

If NEC forces us into postulating SOAs unnecessarily, then NEC would be an ontologically immodest version of truthmaker theory. For instance, if it goes beyond the tasks or possibilities of truthmaker theory (or any theory of the relation between truth and reality) to explain how truths are guaranteed in all possible worlds, then NEC would indeed be immodest as well as unparsimonious. The postulation of SOAs as truthmakers seems to be based not on empirical data or metaphysical reasoning concerning, say, the possibility of instantiation. ${ }^{10}$ Rather, it is based purely on a priori reflection on a property (truth) of linguistic entities (truthbearers) and the intuition, which (only) some of us have, that we are led to metaphysically substantial conclusions (e.g. that there are special entities, namely SOAs, required for truth). Considerations of modesty and parsimony demand that if there is no need to draw metaphysically substantial conclusions just from looking at language, then we should not do so. Can we give an ontologically more modest alternative to this NEC-story about truthmaker theory? The aim of this paper is to argue that ontological considerations about the nature of truthmakers are limited. Considerations of aboutness require us to talk about SOA-like truthmakers, but these need not be ontologically substantial. This allows us to conceive of the tasks of truthmaker theory metaphysically with greater modesty.

\subsection{Exact aboutness and ontological modesty}

By contrast to NEC, consider the exact aboutness account of truthmaking:

EXACT-ABOUTNESS-TRUTH (EAT): truths are made true by the parts (or aspects) of reality which they are exactly about. ${ }^{11}$

\footnotetext{
${ }^{10}$ For instance, and most pressingly, see Dodd (2002: 8, 9, 2009: 331, 332) who rejects SOAs for reasons related to instantiation and especially Bradley's Regress.

11 In tying aboutness to truthmaking, this account generally follows Lewis (1988: esp. §5) in spirit (though diverges in the details). It also more recently closely follows Yablo on exact aboutness insofar as he understands exact aboutness as including proportionality (2014: 39-42) and wholeness (ibid.: 14) requirements (see below). It also follows Yablo in understanding aboutness not as a relation to entities, but as a relation to "how matters may stand so that $S$ is true". As will become clear in the discussion it is a relation sometimes to entities when what we are talking about are indeed entities (perhaps this is the case with existential truthbearers such as 'Susan exists'), but also a relation to how matters stand with entities so that $S$ is true, when this is what $S$ is about (rather than just to entities, as might be the case with existential truthbearers). Yablo explicitly calls aboutness or subject-matter a "dissimilarity relation" (ibid.: 41; emphasis added). Cf. Lewis (1988: 161-164), and see also Fine (2015: 18-21) and Crane (2001: 22ff) for a more detailed discussion and defence of the relational nature of aboutness. I thank an anonymous reviewer for asking me to clarify this.
} 
What a truthbearer is exactly about captures the best semantic account of what it is about (Yablo 2014: 39-42). Exact aboutness has a proportionality requirement (2014: 75, 76) on which "[t]ruthmakers, like causes, should not be overladen with extra detail [ ...] irrelevant extras [ ... or what is not] strictly required" (2014: 75; my emphasis). For instance 'the horse is brown' is strictly about the horse but not strictly about the barn in which it lives or even any parts of it such as its mane or the molecules out of which it is composed. Exact aboutness also has a wholeness constraint. ${ }^{12}$ For instance, 'the horse is brown' is not just about a horse or being brown. Rather, it is wholly about the horse being brown. Thus, it is exactly about the horse being brown (and neither strictly about extra irrelevant details such as the nature of horses or its specific shade of brown, nor wholly about just the horse), which in turn is its truthmaker. ${ }^{13}$

With truthbearers and the aboutness-apparatuses out of which they are constructed, we are able to talk and think about a great variety of entities and also a great variety of ways that these entities can be. ${ }^{14}$ Given this, EAT demands not just that there is a plurality of things but a plurality of ways things are. However such a plurality is metaphysically innocuous. My reason for thinking this is best captured by Lewis when he explains that Bigelow's slogan "Truth is supervenient on being" 15 (Bigelow 1988: 132, 133 and 158, 159) should be understood, as Lewis

\footnotetext{
12 See also Lewis's notion of entirely about explained in terms of that which makes a difference to truth (i.e. truthmakers): "[i]f the statement is entirely about the subject matter, no difference that falls outside that subject matter could make a difference to the truth of the statement" (1988: 11). There are differences between 'wholly about' and Lewis's 'entirely about' which I don't have space to go into now.

13 See also Goodman (1961), in particular his notions of absolute (ibid.: §3) and especially immediate (ibid.: 12) aboutness. Goodman (ibid.: 7f) also defends a wholeness constraint for aboutness, which he argues Ryle's (1933) and Putnam's (1958) accounts problematically lack (he argues that shifting psychological emphasis and the grammatical position of designating expressions should not affect aboutness). 'Crows are black', according to Goodman, is about crows and black things, while according to Ryle and Putnam it is about crows but not black things. (However, see Ryle's discussion of the sense of 'about' he calls "the 'about-substantival' or 'about (s)'” (1933: 10). This sense of 'about' tries to respect the wholeness constraint: for we can use predicates to talk, for instance, "about (s)" being-a-live-dog or the average man (Ryle's examples). This is done, according to Ryle, via "a noun or pronoun or a phrase equivalent to a noun or pronoun occurring in no matter what grammatical position in the sentence" (ibid.). Also, see Ryle's brief discussion of 'facts about Q' (1933: 12), where he claims that "[f]acts are not genuine entities".) Interestingly, Goodman also claims that logically equivalent statements are absolutely about the same things, while they are not immediately about the same things. Thus, 'the triangle is equiangular' and 'the triangle is equilateral' are absolutely about the same things, since they are logically equivalent, while they are not immediately about the same things. Exact aboutness also captures the difference in aboutness: for although they are both strictly about the same triangle, the former is also strictly about being equiangular while the latter is not and is instead strictly about being equilateral. I thank an anonymous reviewer for giving me the opportunity to say more about this comparison.

14 See also Crane (2013: 39).

15 Some think that supervenience is not asymmetric. See, for instance, Bennett and McLaughlin (2014: §3.2) who argue that supervenience is sometimes symmetric and sometimes asymmetric, so in general it's non-symmetric. In general, however, I think Bigelow and Lewis mean to understand the supervenience involved here as asymmetric or at least as asymmetric as the truthmaking relation needs to be. Also, see Merricks (2007: §4) and Rodriguez-Pereyra (2005: 18, 19) who argue that the supervenience thesis doesn't capture the requirement that truth depends asymmetrically on being because truths supervene symmetrically on each other. Also, see Horgan (1993: §8) who argues that
} 
says, as "constru[ing] 'being' broadly: it covers not only whether things are, but also how they are" (Lewis 1992: 218, see also 216; original emphasis). According to Lewis, how things are with an entity $\mathrm{x}$ is not a further entity over and above $x .^{16}$

Similarly, Bigelow writes, "On this view [the second-order quantification view], the claim that there is a somehow that certain things are should not commit us to saying that there is some further thing which is this 'somehow' that they are. The second-order 'there is somehow ...' does not entail the first-order 'there is something ...” (1988: 159). If we understand 'somehow' as relating to properties, Bigelow's point is that to understand second-order quantification properly, we must understand that quantifying over properties (or somehows) does not mean that we are claiming that properties exist; to think otherwise is to conflate properties with things which are indeed claimed to exist when we use first-order quantification.

Nothing about EAT requires us to reify (i.e. claim to be a res or an entity) the ways that things can exist and interpret such ways of existing as separate or further things or entities over and above the entities which are some way. Prior (1971: especially Chapter 3) extends this to the use of predicates, adverbs, and non-nominal quantifiers (such as 'however', 'wherever', 'somewhere', and 'somehow'). We can talk about how or where things are when we say 'I hurt him in some way' or 'I met him somewhere' without being "ontologically committed to the real existence of 'ways' [... or] to the existence of places as well as ordinary objects" (1971: 37). Until recently Prior was one of the very few to talk of non-nominal quantification, and these general insights here have profound consequences for aboutness and truthmaking, as we shall see. ${ }^{17}$ The overall point is also captured by Rayo and Yablo (2001: 79) who argue that "[i]f predicates and the like needn't name to be

\section{Footnote 15 continued}

supervenience cannot capture what is called ontological dependence. However, against Horgan, the truthreality dependence (TD) is neutral about whether the right asymmetric dependence is ontological or nonontological. It is clearly not ontological if what is meant by 'ontological' is that truths depend only on what exists rather than on how what truths are about exists. That my account rejects such an ontological reading of TD should be clear from the discussion in this section.

16 Lewis (2003) talks about SOAs as truthmakers but these are distinguished strictly from Armstrong's SOAs. The latter are explicitly further entities, while the former are not. Lewis (2003) and Lewis and Rosen (2003) understand SOAs as "qua-versions" of things. The operator '... qua F' in 'a qua F' evokes the fine-grained counterpart relation selecting all the counterparts of $a$ in all possible worlds where $a$ is F. See MacBride (2005: 129-131) who directly contrasts Lewis and Rosen's view with Armstrong's on the grounds that Armstrong requires entity-explanations of truths while Lewis and Rosen don't. The view endorsed in the current paper is even more neutral, for (1) it acknowledges that these are all live options, thereby already blocking the entailment to truthmakers as entities; and (2) since when we talk about an object having a certain property, it doesn't seem as if we are taking about the object's counterparts in other possible worlds as well. But we need not settle this issue here.

17 However, it is tricky to extend this thinking also to places as he does, for places seem to be objects which can have parts and can be visited, etc. However, Pietroski (2005: 276) agrees with my general point that it doesn't follow from something, including a place like France, being a truthmaker and thereby real that it is an entity.

Also particularly relevant is Prior's (ibid.: §3.6) discussion of $\lambda$-conversions in which he argues that "[t]he Platonistic implications of the use of abstraction-operators [...] seem to me to be exaggerated" (ibid.: 45). Although I won't speak directly about the $\lambda$-conversions, Prior's points are relevant to what I say about aboutness and nominalisation $(\$ 2.2)$. 
meaningful to make their characteristic contribution to truth-value then we have no reason to regard them as presupposing entities at all". ${ }^{18}$ And, indeed, predicates clearly function differently from singular terms and names: singular terms refer to and are thus about entities, while predicates say something about how things are with the entities. ${ }^{19}$

Dodd makes the same points, in the context of considering the truthbearer 'the ball is red at time $t^{\prime}$, when he says,

For there would seem to be a possible world [where the truthbearer is false] which contains the same existents as the actual world but in which the ball in question is not red at $t$. The difference between these two worlds lies, not in what exists, but in how things stand with what exists. In the actual world the ball instantiates redness at $t$, in the imagined possible world it does not. Period. The truth of $<$ The ball is red at $t>$ is not, it seems, determined by the existence of some entity (viz. a state of affairs or trope [i.e. a particularised property, PAP, for short]); it would seem to be true because some entity (viz. the ball) has the property in question at $t$. [2002: 74]

What Dodd and these other ontologically modest theorists are saying is that no new or separate entity needs to exist for the truth to be true. The difference between the world where the truthbearer 'the ball is red at time $t$ ' is true and the world where it is false, is not a matter of what things exist, but rather a matter of, as Dodd says, "how things stand" (ibid.) with what exists. Dodd's target is those truthmaker theorists who think that truthmakers must be entities.

EAT, by contrast, presents the truthmaker theorist with a more modest option of understanding truthmakers as entities and how things are with those entities, without introducing further complex or basic entities. This comes down to what the best semantic account of aboutness (SEM-TAC, for short) says that truthbearers are about and hence what parts and aspects of reality the account says are their truthmakers. And, these may be various for each truthbearer: some truthbearers are

\footnotetext{
18 They follow Quine's (1948: 10, 11) “ontological innocence" (Rayo and Yablo ibid.) with regard to adjectives and other non-nominal phrases. (Their discrepancy with Quine is echoed in my later discussion as well.) Wright sums this up as the "Neutrality" principle (2007: 153) (see also Fine (2015: 18-21, 2017: 1, 2012: \$3) who presents and defends a neutrality requirement on truthmaking and for truthmaker semantics). He goes further, however, and argues for what he takes to be a "modest claim: precisely, that quantification is neutral as far as ontological commitment is concerned-that the commitments of quantified statements go no further than the requirements of the truth of their instances whatever the latter requirements are" (ibid: 154). Thus, he extends this ontological modesty or "ontologically liberating conception of higher-order quantification" (ibid.: 154) to quantification in general. Predicates do not name anything and thus do not incur any additional ontological commitments. Existence-implying quantification is a special case of quantification, where "the term quantified into is functioning referentially" (2007: 160). See also Williamson (2003: 254-259).

19 See also Rosefeldt (2008: 312) who argues that non-nominal quantification, e.g. 'There is something Clara and Cindy are, i.e. shy', cannot be analysed in terms of entities: e.g. 'There is an entity $x$, such that Clara is $x$ and Cindy is $x$ ', for the latter is ill-formed if the variable ' $x$ ' is understood as an individual variable. One cannot substitute the variable with a singular term, e.g. 'Clara is shyness' is ungrammatical.
} 
about various entities and various ways things are with those entities, e.g. 'The rosycheeked girl loves grabbing the queen whenever she wins at chess from her grandfather'. Why should we demand that the truthbearer is about some unique and single truthmaker: the SOA the ball's being red at time $t$ or the SOA The rosycheeked girl's loving...? Rather, in each case, it is more plausible to think that multiple sub-facts combine to make the truthbearers true. ${ }^{20}$ Following Austin (1979: $124,125)$, we may reject that truth demands a structural isomorphism between truthmaker and truthbearer, where truthmakers must be unique objects in the world whose structure mirrors the structure of the truthbearers they make true. If we reject unique aboutness, that is that there must be a unique thing or entity that any particular truthbearer is about, then it seems perfectly adequate and open to the truthmaker theorist to say that the truthmakers are the object the ball and how things are with the ball at time $t$, all of which are how things are with the reality that the truthbearer is about. There is no reason to reify how things are as a SOA. Such a reification would be a step too far.

The modest approach to truthmaking accepts the basic claim that if $p$ is true, then something makes it true. But, this something need not be an object or entity. The English word 'something' coupled with 'makes' need not be a way of speaking that brings in objects. Consider: 'Have you forgotten something? Yes, I've forgotten to open the window!'. This answer doesn't pick out an object. Similarly, what we talk about and what makes what we say true need not be objects. $^{21}$ In fact, the best SEM-TAC might require only that we posit what Dodd calls "sub-sentential language/world relations" (2002: 74, 75) ${ }^{22}$ and their relata. Dodd (2002: 78-81) argues that given such sub-sentential language/world relations one need not posit any entity or "that there must exist some thing" (ibid.: 79) to account for any truths but rather that truth supervenes or depends on "how things are" (ibid.: 79). This is an important insight. Dodd is stating that given the existence of the sub-sentential language/world relations there is no need to posit a SOA (as Armstrong does) to account for the relevant truths. A dependence on how things really are is not a dependence on the existence of some further entity how things are, but, rather, a dependence on the being or reality of how things are.

One way to understand this is via the suggestion that not all quantifiers are entitative or objectual and that such nonobjectual quantifiers are not ontologically committal. $^{23}$ If we understand talk about ways things are, for instance 'there are better ways to show your daughter you love her than to buy her more toys', as talk about how things are, then it becomes clearer that we aren't objectually quantifying

\footnotetext{
${ }^{20}$ I thank an anonymous reviewer for helping me clarify my point here. See the next paragraph too for some more clarification.

21 I want to thank Paul Snowdon here and also for our always inspiring conversations.

22 Dodd also calls them "sub-sentential thought/world relations" (2007: 398).

23 See Rayo and Yablo (2001: especially 77-82), and Yablo (1996: 267, 268).
} 
over ways, as we would be if we were quantifying over the objects which are the ways. We cannot count the number of ways things are, neither in general nor for any particular thing. In fact, it is via our talking about ways things are that we can count objects. For instance, we can't just count the number of things in a room, but we can count the number of red and mammalian things. ${ }^{24}$ Thus, we must be able to talk about ways things are and also distinguish between them, but they are not entities themselves over and above the entities which are those ways. But we still quantify over ways and we quantify over how things are, for instance when we say that something is somehow or some way. However, this quantification is clearly not objectual or ontologically committing.

Dodd (2002: 77) and Lewis (1992: 218) call the supposed ontological consequences of NEC "an over-reaction". EAT avoids such an over-reaction by being free from strong metaphysical commitments. All we need is that the entities that the truthbearers are about exist and are how they are described to be, as long as the truthbearers are truthbearers which make positive claims about the way the world is. This claim is compatible with the various strong metaphysical versions of truthmaker theory. But, importantly, it does not entail any of them. For it is completely compatible with accounts that say nothing about the ontological and metaphysical nature of what the truthbearers are about. It is far from obvious that the best SEM-TAC has to say anything about the ontological grounds (in Armstrong's sense or any sense) of truths. Consider the following claims

T2: The table is round.

T3: There are giraffes.

EAT merely requires that the entities that $\mathrm{T} 2$ and $\mathrm{T} 3$ are strictly about (the table and giraffes) indeed exist, and are the ways they are described to be. For either of these claims to be true, if EAT is adequate for truthmaker theory, there is no need to say anything more about the nature of tables, the nature of roundness, or the nature of giraffes, and there is definitely no need to require the existence of some unique, metaphysically substantial, but also, to many, mysterious, entity, the SOA the table's being round.

Here's another argument for the claim that EAT is metaphysically much more modest than these stronger metaphysical versions of truthmaker theory. EAT is compatible with the metaphysical worldviews such versions espouse without entailing any of them and hence without favouring any of them. Let us conceive of some possible worlds $w_{m}, w_{m+1}$, to $w_{n}$ where there are only SOAs in those worlds and also conceive of other possible worlds $w_{n+1}$ to $w_{p}$ where there are only nontransferable particularised properties (PAPs). ${ }^{25} \mathrm{I}$ can clearly and distinctly conceive of each world. When Jonny says, "I think. I exist.", both of these truthbearers are true if Jonny and his counterparts utter them in worlds $w_{m}$ to $w_{p}$. In these cases, because there is nothing in those worlds but SOAs and PAPs, their truthmakers will be either of these. But, what they are about is exactly the same in those worlds: the

\footnotetext{
24 See also Beaney (2017: chapter 1).

25 See Mulligan et al. (1984), who take truthmakers to be modes, which are particularised properties (PAPs).
} 
first truthbearer is about Jonny and how things are with Jonny, that is, that he's thinking; the second truthbearer is about Jonny and his existing. Whatever the deep story of the ontological nature or category of the truthmakers in the different worlds, the truthmakers are the same-qua-truthmakers-for-these-truthbearers. In worlds $w_{m}$ to $w_{n}$ the truthmakers happen to be SOAs and in worlds $w_{n+1}$ to $w_{p}$ the truthmakers happen to be PAPs. Nothing about the truth of the truthbearers nor EAT entails that truthmakers can only be one or the other or that they must be either. Such neutrality is at the heart of metaphysical modesty. So, EAT is metaphysically modest in ways that other accounts are not.

I have not argued that SOAs do not exist. One may argue for or against the existence of SOAs (or PAPs) on independent grounds. But, that is not my concern. I have merely argued that SOAs and PAPs are not necessary for truth. I have objected against the truthmaker-argument for their existence. According to the modest view I am proposing, the truthmakers are just whatever the truthbearers are strictly and wholly about. Thus, unless a commitment to such metaphysical matters is essential to the best SEM-TAC - and in no way does this seem to be the case-one can remain neutral as to whether truthmakers are SOAs or PAPs or whatever else of metaphysical substance.

\section{An illustration of the importance of getting right what we are talking about: states versus events}

In this section, I shall present and discuss two arguments that have been used to argue for a categorial distinction between states and events on the basis of the semantic features of truthbearers used to talk about them. The orthodox truthmaker account would interpret the categorial distinction as an ontological distinction between kinds of entities. EAT's modest view of truthmakers will, via its aboutness-machinery, provide us with a theoretically more virtuous and intuitive alternative interpretation.

Both arguments are meant to lay out the distinction between states and events by marking out the differences in how they fill time. From these differences in syntactical and semantic categorisations, Marcus (2009) and Steward (1997) ${ }^{26}$ both draw the conclusion that these are not "just a by-product of grammar" (Steward ibid.: 95) but that there are corresponding distinctions in categorial ontology. ${ }^{27} \mathrm{~A}$ distinction in categorial ontology is one in which we draw a distinction between kinds of entities. To draw such a conclusion from the linguistic evidence relies on a substantial account of the truth-reality (i.e. the truthmaking) relation. $^{28}$ In particular, their central

\footnotetext{
26 They do not stand alone; in a canonical paper, Gendler-Szabo (2004: §1) argues that "how the recognition that progressive sentences do not entail their perfective correlates made it clear that such a semantic analysis must presuppose a richer ontology than that of classical tense logic" (ibid.: 31). This is the "imperfective paradox," which I discuss below. Gendler-Szabo uses it to enrich his ontology; merely quantifying over possible worlds or events, as he argues (ibid.: §2), is not satisfactory.

27 Steward thinks that denying this would be "unduly dismissive of the importance of grammatical distinctions for ontology" (1997: 95).

28 Thanks to E. J. Lowe and Jennifer Hornsby for making this clear to me.
} 
argumentative move is to point out that one must not change the subject matter when talking about states by slipping into talking about events. In other words, to get their ontological argument off the ground, they rely on our intuitions as to what the syntactic and semantic features of truthbearers tell us the truthbearers we use are about.

In what follows, I argue that their moves rest on an unwarranted understanding of truthmaker theory. All that truthmaking requires, if we accept EAT, rather than NEC and other metaphysically substantial accounts, is that there is a difference in how things are and not a difference in what things there are. For instance, consider the state John's being happy and the event John's crossing the street. Neither the state nor the event involving John exist. The thing that exists in these cases is John. The states and events are just how things are with John (and perhaps other things too, such as the street, since John is crossing the street); in the former, he is happy; in the latter, he is doing something, that is, crossing the street. Of course, truthbearers which are not strictly and wholly about the same thing require differences in reality to make them true. Steward and Marcus are clearly right that the syntax and semantics mark a difference in what the truthbearers are about, but this difference can be understood as a difference in being in the sense that there is a difference in how things are, rather than in what there is. To make this further step would be to accept NEC.

\subsection{The argument from aspectual markers}

\section{Consider:}

T4: Margot told me something.

T5: Margot was telling me something.

Both are perfectly good truthbearer-constructions that make sense. However, there is a crucial difference between their syntactic structure. In T4, the verb-predicate is not in the continuous form and thereby has what is commonly called a "perfective aspect". In T5, the verb-predicate is in the continuous form and thereby has an imperfective aspect. Moreover, the indicated event in T4 can be viewed or considered as a whole in its entirety from our perspective in the present. T4 indicates completion: that is, there was a telling that has finished. By contrast, T5 indicates that something was in the process of happening: the telling was on-going but may have been interrupted or stopped before being completed. And because of this, T5 does not entail T4. ${ }^{29}$

Both T4 and T5 are sentences about events. ${ }^{30}$ This is indicated by the use of the event-verb 'to tell'. When we consider other event-verbs, such as 'to walk', 'to show', 'to fill', we can easily construct truthbearers where the verbs are in either the

\footnotetext{
${ }^{29}$ Gendler-Szabo (2004: 32) calls this the imperfective paradox.

30 Some might argue that truthbearers such as T5 do not pick out an event, but rather something of a completely different category, namely a process, or following the Vendler-Kenny categories (see Vendler 1957: 148ff; Kenny 1963: §8), an activity. Following Parsons (1985: §9), I'll mainly just talk about truthbearers such as T5 as if they pick out and are about processes understood also as events. See also Galton (2012b: 286) who suggests that processes might be dynamic states: a state of change, although he also acknowledges differences between states and processes.
} 
perfect or imperfect tense: 'Joe walked across the street' or 'Joe was walking across the street'; and 'James showed me the way' or 'James was showing me the way'; and 'Jane filled the cup' or 'Jane was filling the cup'. All this seems to indicate that the perfective/imperfective distinction arises in the case of events, and that they are thereby the kinds of things that can begin and finish, or remain unfinished. These are the features of the temporal shape of events and show how they fill time.

By contrast to how things are with events, when we look at states, and the corresponding truthbearers about states, the perfective/imperfective distinction does not arise. Consider parallel truthbearers in the case of states:

T6: Ed believed that Corbyn is a socialist.

T7: Ed was believing that Corbyn is a socialist.

In this case, despite its oddity, ${ }^{31} \mathrm{~T} 7$ entails T6. Whenever T7 is true, T6 is true. Whenever anyone $S$ was believing $p$, then $S$ also believed that $p .^{32}$ Truthbearers in the continuous form such as T7, when they contain stative-verbs do not have the same implications as sentences such as T5, which contain event-verbs. While T4 and $\mathrm{T} 5$ are distinct in the way they capture the different temporal aspects of events, the different grammatical constructions of T6 and T7 do not capture any differences in the temporal aspects of states. It seems, then, that the perfective/imperfective distinction does not arise with state-truthbearers.

One way to understand what is going on with the syntactic and semantic features of such expressions is that they indicate important differences in the way states and events, as categorially distinct entities, themselves fill time. This is the way favoured by Marcus (2009: 219-222). On his understanding, an event is the kind of entity that has temporal parts, as it is not wholly present in each of its time-intervals. Also, an event clearly begins and ends, meaning that there is a clear sense in which an event can be said to start to occur, be in a process of occurring, and then finish or come to completion. Unlike events, it does not seem as if states are the kinds of entities that have temporal parts, since they seem to be wholly present at each interval, a feature commonly called homogeneity, ${ }^{33}$ and because of this, they do not have a beginning or an end.

\subsubsection{Objection 1: describing entities}

The distinction made between states and events so far is clear enough. However, it should be noted that the distinctions are marked at the level of predication, that is, the way that the entities such as Ed and Margot are described to be or behave, not at the level of entities, that is, we have not established a distinction between

\footnotetext{
$\overline{31}$ No native speaker of English would normally say a sentence such as T7. But this does not affect the argument.

32 Talking about degrees of belief wouldn't make the entailment invalid and wouldn't make these two come apart. There is no sense in which someone can be believing something to degree $\mathrm{X}$ and not believe it to degree $\mathrm{X}$.

33 This is the common name for this feature especially in the linguistics literature; see Galton (2006: 5, 2012b: 286) for a discussion of processes as homogeneous and events as lacking homogeneity in this sense.
} 
truthmaking entities. These features of event-descriptions, as yet, do not have conclusive consequences for an ontology of events-as entities distinct from other entities such as objects. Some philosophers think that events are coarse-grained entities; see for example Quine (1985: 167f), who individuates events according to spatio-temporal co-extensiveness, ${ }^{34}$ and Davidson (1969: 179f), who individuates them according to their causal role. They would need to explain how an unspecified event, for instance the ball's having moved, and a specified event, the ball's having moved from one end of the pitch to the other, can be the same entity, despite the differences in event-descriptions. This, however, cannot be decided or explained at the level of description, but would need to be explained at the level of metaphysics and would include considerations to do with causation and spatio-temporal identity. So, drawing the conclusion that there is a distinction in kinds of entity, based solely on the linguistic distinctions presented, is premature at best.

A more relevant comparison may be that one can often tell just from two eventdescriptions that they do not pick out the same event, e.g. the ball's moving is not my sleeping. ${ }^{35}$ Even here, however, what allows one to make a distinction among events is not the event-descriptions but important background knowledge about the world and the context: knowing that there are distinct objects involved, that is, knowing that I am not a ball, and knowing that we are talking about two different ways these objects can be, sleeping vs rolling. We can only so easily read off a distinction among these events because of an understanding of the entities and how things are with the entities with which we are already familiar; we are not reading off a distinction in ontology from the descriptions themselves. The distinction made between event-descriptions doesn't entail a corresponding distinction among events as entities (though there is a clear distinction between other entities: the ball and me). But, we neither have a distinction between events at the level of entities nor between events and objects, where both would need to be considered to be entities.

A fine-grained event theorist, such as Kim (1966: 321ff, 1976: 34ff), ${ }^{36}$ will have to explain in what sense some unspecified event and some specified event, despite being distinct entities (on their account), are both the same kind of entity, despite the differences that occur in their descriptions. This will most likely involve a story about the nature of the properties associated with events, rather than further data to do with event-predications. ${ }^{37}$ In fact, this metaphysical story will have to be convincing despite the linguistic data presented.

EAT's pluralism and neutralism, by contrast, allows us to take these descriptions to mark linguistic or semantic distinctions which map real differences in how things must be if these truthbearers are true, rather than ontological distinctions as the philosophers

\footnotetext{
34 See also Lemmon (1967: 98, 99).

35 I thank an anonymous reviewer for raising this point.

36 Kim considers events to be property-exemplifications.

37 Kim (1976: 33), for instance, briefly explores the idea that events are changes and states are "unchanges" (ibid.). Taking this suggestion on board, one might try to develop a theory of staticproperties and change-properties metaphysically to underpin the distinction. Kim (ibid.) quickly gives up on this idea however, given the fact that there are many hard cases for classification, such as having a throbbing pain in the right elbow. See also Steward (1997: 72-74).
} 
I have just mentioned take them to be. This, in turn, lets us avoid having to consider the difficult (perhaps, unsolvable) ontological issues to do with event individuation and identity. ${ }^{38}$ One can be pluralist about the various ways that the ball is, was, and can be without having to take any of these ways as entities in their own right. Although this pluralism indicates that these are differences in reality, the linguistic evidence doesn't seem to mark a difference in ontology, that is, in the kinds of entities there are. Thus, there is no need to distinguish such ways of being from the ball (as object) and from other ways the ball is, at least not in terms of distinctions in ontological, rather than linguistic, categories.

\subsubsection{Objection 2: can states be in the process of finishing?}

Now I want to discuss another objection, which is most relevant to our purposes and reveals an important part of a successful truthmaker-strategy. The objection is that it seems that we can, very well and meaningfully, understand T7 in such a way that it contains reference to a state which is in the process of finishing.

However, taking the phrase 'was believing' to indicate that the state is in the process of finishing and taking 'believed' to indicate a finishing of belief, such that T7 does not entail T6, will actually change what we are talking about, and uses the term 'belief' in a different way than if we would take it to refer to a state. ${ }^{39}$ One may sensibly talk about someone having believed something. But this is consistent with the use of 'beliefs' to talk about states. It does not involve anything having finished doing anything or completing anything since a belief-state is not the kind of thing that finishes or comes to completion. Margot will not have finished or completed her believing at any point of her having the belief. Once she believes something, she continues to believe it until she changes her beliefs. ${ }^{40}$ The fact that we can interpret the stative verb-phrases in such a way as to indicate that the belief actually finishes merely indicates that we can use these phrases in a different way than the ordinary way in which we use them, that is, to talk about states, which do not finish in the relevant sense. If we adopt this other interpretation and take the verb-predications to tell us something different about the way these entities fill time, what we're doing is changing talk about states to talk about something else, and in this case, events. When we say that Ed has believed that Corbyn is a socialist, to indicate that he believed and has finished believing this, we are not talking any more about the state of belief that Ed was in, but rather about something else, an event in his mental life, such as perhaps the interval in which there was a change in belief. This does not

\footnotetext{
38 Gill (1993), for instance, also criticises Mourelatos and argues that "the differences between processes and events [on the basis of linguistic issues] cannot provide the basis for an ontological subcategorization of occurrences" (ibid.: 366).

39 The stative-use of 'belief' is the ordinary English usage of such words. See Marcus (2009: 216).

${ }^{40}$ Of course, neither her having this belief nor her changing her beliefs need be conscious. Much like other things we hold dear as important parts of ourselves, such as one's weight, one can gain and shed beliefs without being aware of what's happening to one's (implicit) world-view.
} 
show that believing is an event rather than a state, but rather that we can use stativeterms such as 'believing' to conform to talk about events. ${ }^{41}$

Marcus (2009: 29) aptly describes this move as "changing the subject" (ibid.). It seems then that 'believing', taken as a stative-verb has characteristics importantly different from others that are event-verbs. The distinction between perfective and imperfective verb-aspect holds in the case of event-predication but not in statepredication. So, states do not fill time in the same way that events do. In a discussion of states, if one were to start using the grammatical behaviour which indicates that one is talking about events, what one is clearly doing is just changing the subject. But what is the significance of this?

\subsubsection{Don't change the subject matter!}

Marcus (2009: 216) suggests that using 'belief' and other such nouns such as 'depression' or 'desire' to talk about states is the ordinary English usage of such words. I agree with this, but as I shall discuss in this and the next section, Marcus thinks that one can draw ontological conclusions from the categorial distinctions that we made in the preceding sections and from the fact that state-and-event talk is entrenched in ordinary usage.

The ordinary usage of these words does not have any direct bearing on ontological conclusions about whether the category of state is fundamental or not. In particular, even though it is true that such terms are used to talk about states in the way set out, and that states have the features identified in the discussion, it is not clear yet that a distinction is being made in terms of ontological category, that is, a distinction in kinds of entity. The different features of the event-verbs and stateverbs indicate a difference in what we can talk about. But, this may not be any more than a difference in "how things stand with what exists" (Dodd 2002: 74).

The ontologist might respond by pressing a possible advantage of her account by saying that it is (1) a non-trivial and metaphysically interesting question whether one way of standing is different from another way of standing, and (2) that it is clear enough what the difference is if ways are things: they are two different things. ${ }^{42}$ Rayo and Yablo (2001) have an interesting and relevant point here which can be made in response. They agree with Quine that adjectives and other non-nominal phrases are ontologically innocent when he writes:

the word 'red' [...] is true of each sundry individual entities which are red houses, red roses, red sunsets; but there is not, in addition, an entity whatever, individual or otherwise, which is named by the word 'redness' [...] McX cannot argue that predicates such as 'red' [...] must be regarded as names each of a single universal entity in order that they be meaningful at all. [1948: 10, $11]$

\footnotetext{
${ }^{41}$ Conversely, the distinction between unspecified and specified events that I introduced in the previous section, perhaps, marks a way to use what are normally thought of as event-verbs to talk about states.

42 I thank an anonymous reviewer for raising this potential response from the ontologist.
} 
But they disagree when Quine says: "one may admit that there are red houses, roses, and sunsets, but deny, except as a popular and misleading manner of speaking, that they have anything in common" (ibid.). First, one can't infer the latter from the former. Just because redness is not an entity, it doesn't follow that entities can't have redness (or anything else) in common. In fact, it seems odd and unnecessary to think that what one must have in common with others if one has something in common with them needs to be an entity, as might be the case when one shares a bank account or co-owns a dog with one's partner. Having being red in common seems to be very different from having a dog or bank account in common, but that doesn't mean that two things can't both be red. Second, consider 'There is something that roses and sunsets are' and 'Roses and sunsets are red'. The second is a substitution instance of the first, an existential generalisation. But, existential generalisations are no more committal than their substitution instances. So, the first has no more commitments than the second. And, since the second is not committed to anything but roses and sunsets, neither is the first. ${ }^{43}$ Thus, in response to the ontologist, similarly in the case of property-differences, e.g. 'The rose is red' and 'The rose is wilting', the inferable existential generalisations (e.g. 'There are two distinct ways that the rose is') are not committed to any more than these instances. That is, they are not committed to more than the rose, although they are made true by different truthmakers: the rose and the different ways that the rose is.

Marcus's point about entrenchment indicates that we use the terms I presented at the beginning of this section to refer to states ordinarily. The move made above of forcing belief-talk to follow the logic of event-talk amounts to changing the subject. To use terms such as 'belief' to refer to events would be to use them to talk about something different from, though perhaps also similar to, what we normally talk about. Marcus writes, "changing the subject amounts to changing the semantics of belief-talk so as to make it conform to the model of event-talk. But this doesn't show that beliefs are events, only that we can use the term 'belief' to pick out events" (2009: 219). ${ }^{44}$ This is an important point. One must make sure not to change the subject and not change the semantics and logic of the subject matter. This is at the heart of my insistence that aboutness and knowing what we are talking about is central to the right theory of what makes truthbearers true. When we use truthbearers about states and when we use truthbearers about events, there is an important difference in how the world is that makes true these different truthbearers with categorially different semantic features.

\subsubsection{Changing the subject is not talking about a different entity}

However, it is a large jump from thinking that we are talking about states and events understood as the intentional objects ${ }^{45}$ that we are talking about when we use

\footnotetext{
43 See Rayo and Yablo (2001: 79, 80).

44 Marcus doesn't seem to have anyone in particular in mind here when he makes this point, except perhaps the hypothetical theorist who might try to put belief talk into event talk.

45 I follow Crane (2001: 23) in his presentation of what intentional objects are. The important point is that they are not substantial.
} 
certain state-verbs and event-verbs in a truthbearer to thinking that the truthbearer as a whole refers to or is about an existing entity, the state or event. What is important is that we can still talk about how things are with what exists without committing ourselves to the existence of how things are with what exists. As is indicated by the discussion so far, we can even distinguish between different ways that how things are with what exists can fill time. States seem to persist through time, while events take time. However, this may also just be a way describing and talking about how things are with the subject. When Ed believed that Corbyn is a socialist throughout time interval $i$, he will have believed this throughout every subinterval of time within $i$. We can talk about this feature of the subject. And, indeed, this feature concerning him is different from the subject itself or its existing. We are talking about how he existed, not just about him or that he exists. However, this does not mean that there is a state of him, understood as a separate entity, existing throughout this period which has these features throughout this period. Ed and how things are with him is all that the best semantic account of what T6 and T7 are about requires in terms of truthmakers for these truthbearers. Similarly, in the case of event-talk, $\mathrm{T} 4$ and T5 merely require the intentional worldly satisfaction of T4 and T5 for them to be true. And all this requires is that Margot exists and for things concerning Margot to be how they are described to be. This means that Margot's telling me something is indeed importantly different from Margot having told me something because how things are with Margot is different in each case. The latter entails that she told me what she was telling me, while the former does not. For Margot might not finish telling me what she is telling me (for instance, because of something trivial such as her changing the subject mid-sentence, hence not completing what she was trying to say). ${ }^{46}$

These semantic and syntactic differences and the consequences they have for the categorisation of how things can be for someone or something, and also for the general linguistic categorisations we can make about event- and state-verbs, is indeed very important. I think that the best way to understand them is as a difference in truthmakers and truthmaking. However, this does not require us to go the step further and claim that there are consequences for ontological categories pertaining to what exists. This would only be warranted by the kind of NEC move that also reified SOAs, a move that Lewis calls an "over-reaction to something right and important and under-appreciated. What's right, roughly speaking, is that truths must have things as their subject matter" (1992: 218). Lewis clearly doesn't take this talk of "things" ontologically seriously, however, for he explicitly makes a distinction between subject matters that are entities and those that aren't (e.g. me and how I feel tonight). ${ }^{47}$ Truths not only have things as their subject matter, but also how things are with those things. And this latter must not be thought of as an additional thing.

\footnotetext{
$\overline{46}$ It has been suggested to me that this is perhaps a Quinean point.

47 Lewis clearly uses the word "things" modestly. This is also supported by his use of the phrase "roughly speaking". See (1988: 12,13) where he distinguishes between subject matters as entities and subject matters not as entities: "Sometimes we have a suitable entity [...] But we cannot rely on doing the same in all cases, as witness the subject matter: how many stars there are". I suggest that a piecemeal approach is preferable: look in each case to find out what we are talking about; sometimes that involves
} 
Marcus is right to think that we're changing the subject matter when we're analysing state-verbs (such as 'believes') with an event-semantics. But to think that states and events must exist as the truthmakers for such truths, is an unwarranted over-reaction spurred on by an acceptance of the wrong kind of truthmaker theory. At best, the metaphysical status of the different categories that we're talking about is left under-determined by the semantics.

Of course, perhaps there are further features of the semantics that have been left out of our discussion. But when considering the aspectual shape alone and what reality must be like for these truthbearers to be true, the metaphysical status of the things we are talking about is left undetermined by the commitments of the world being the way it is talked about in the truthbearers. This is also perfectly consistent with the truth of the truthbearers depending on reality, and not the other way around (preserving asymmetric dependence). EAT will have the consequence that there is some worldly difference concerning the truthmakers of state- and event-talk, but the difference is much less metaphysically weighty than other theorists claim them to be. Importantly, what EAT allows us to do is to remain neutral as to whether the semantic differences that are clearly marked out by the semantic features of certain verbs (and we might extend this point to other expressions as well) has any consequences for what things exist, that is, metaphysical/ontological consequences. $^{48}$ It seems that the semantic features do mark out a difference in how things are. States and events seem to constitute, at the very least, different kinds of ways things can be. ${ }^{49}$ However, there is no reason on linguistic grounds based on aspects [and if Dodd (1999) is right, for other grounds as well] ${ }^{50}$ to think of them as anything more substantial, such as SOAs.

\section{Footnote 47 continued}

entities, sometimes not entirely. I thank an anonymous reviewer for letting me say more about Lewis here.

48 Marcus for instance makes a further distinction between states and events based on further linguistic evidence from Galton (1984: 24). However, even Galton (ibid.), many of whose points about verb-aspect Marcus relies upon in his discussion, would reject Marcus and others' use of his points to draw significant ontological conclusions. He thinks that the distinction between states and events is "a distinction between two different ways we have of describing [what goes on]" rather than a "distinction inherent in what goes on" (ibid.). Marcus (2009: 231, 232) argues that "Galton misunderstands the significance of his own work" (ibid.: 218). See also Galton (2012b) who explores the relationship between states, processes, and events in causation. He argues that states cannot be causes (ibid.: 281ff), but that they are involved in complicated causal and cause-like relations (ibid.: 284), such as allowing, termination, prevention, etc., with processes and events. Although many of these relations involve mainly instances rather than types of states, processes, and events, there does not seem to me to be any requirement on the basis of these causal considerations to take any of them to be entities. At most they require a kind of realism which is compatible with everything I say (see $\$ 2.3$ below and [ibid.: 291]).

49 As I said, Galton (2012a: 35ff) has his own non-substantive theory. On the theory that I am suggesting, one might think of them as different modes of being in the sense of being answers to how things are with the individuals and objects involved.

50 See, however, Bennett (1988: 4ff) who following Vendler uses different sorts of nominalisations (e.g. imperfect vs perfect), to build further arguments. 


\subsection{The argument from countability and nominalisation}

A final feature of the semantics and syntax that I want to consider concerns the semantics of nominalisation. This is meant to mark out an ontological contrast between events and states, which is supposed to reveal a difference in countability. This contrast is drawn by Marcus (2009: 227) and Steward (1997: 89). They take the contrast from Mourelatos, who introduced the concept of a "nominalization transcription" (1978: 426) to try to argue that the distinction between mass- and count-nouns runs deeper than just the role it can play in categorising predications. $^{51}$ Consider for example the truthbearer:

T8: Margot walks to Russell Square.

The use of the verb in T8 indicates an event rather than a state. T8 can be standardly nominalised as:

\section{T9: There is a walking to Russell Square by Margot.}

In the case of this event-nominalisation, the presence of the indefinite article ' $a$ ' before 'walking' is supposed to indicate that the correct analysis of T9 is that there is an existential quantifier ranging over a countable governing it. ${ }^{52}$ It thus makes complete sense to say 'Margot walked to Russell Square more than six times in her life', which can be nominalised as 'There were more than six walkings of Margot to Russell Square in her life'. Because events are countables, the event-nominalisations are count-quantified, and the event-predications are easily redescribed in this manner. This seems to hold in general for event-nominalisations. It seems to make complete sense, for example, when we say 'There was a running' or 'There was an explosion' or 'There were twenty reachings.'

State-nominalisations, Mourelatos (1978: 428, 429) argues, are different. Consider:

T10: Ed loves Justine. ${ }^{53}$

Take its nominalisation:

T11: There is love for Justine from Ed. ${ }^{54}$

In this case, there is no indefinite article. This seems to indicate that there is no quantifier ranging over countable particulars in this case. Now consider the alternative nominalisation:

\footnotetext{
51 This more modest, linguistic claim concerning merely categorising predications is made by Leech (1969: 134-137) in the context of the distinction between states and events. His book provides much of the linguistic data on which the philosophers I mention build many of their claims.

52 See Steward (1997: 89-91).

53 By some criteria 'loves' is a non-stative verb. For instance, 'one thing I did today was love my country'. These sorts of cases are addressed below. I'm indebted to an anonymous reviewer for pointing this out.

54 Alternative nominalisations can also be: 'Ed's loving of Justine', or 'the loving of Justine by Ed'.
} 
T12: There is a loving for Justine by Ed.

Or another nominalisation of the same sort of truthbearer (analogous to the eventnominalisation above):

T13: There are six lovings for Justine by Ed.

It seems less awkward to say:

T14: There was much loving of Justine by Ed.

According to Marcus (2009: 277), following Mourelatos (1978), we do not say T12 and T13, but we do say T14. In the same way, when we consider ordinary stuffs such as water or gold we would not be able to quantify over countables, but rather we would need to mass-quantify. For example, it makes sense to say 'There was water in the lake' or 'There was a lot of water in the lake,' but we would not say 'There was a water in the lake' or 'There were 100,000 waters in the lake. ${ }^{55}$ This is evidence for the fact that state-nominalisations are, like stuff-nominalisations, massquantified and not count-quantified. By exploring Mourelatos's strategy of nominalisation transcriptions, we can see that there is a fundamental difference between event-nominalisations and state-nominalisations in terms of which kind of quantifier is appropriate.

Marcus (2009: 228) suggests that a plausible explanation for this is that events are countable entities while states are not; Steward also explicitly argues on this basis that states are states of affairs or facts, as "essentially structured entities" (ibid.: 114). According to Marcus (ibid.), to accept T12 and T13, is not to talk about states but rather to change the examples in these cases to events. Talking about events and talking about states in each case is not fixed by the verb or predicate one uses, such as 'love' or 'hate', but rather is fixed by how the predicates and verbs are used. For different kinds of nominalisation indicate different ways they can be quantified, and importantly indicate totally different categories, or modes of being.

However, Steward (1997: 119, 120), who applies this point to questions to do with the nature of mental states, considers an objection to the idea that states are not countable and that state-nominalisations are not count-quantifiable. The objection is that some of the paradigm examples of mental states, beliefs, desires, and pains, seem to be count-quantifiable. For example, it is very natural to say that Jonny has a pain in the gut, and paraphrase this as 'There is a pain in the gut of Jonny.' However, as Marcus would suggest, when we start talking about beliefs, desires, and states, or any of the usually stative-nouns as count-quantifiable, we are merely changing the subject, or in presently relevant terms, we are talking about different things. Steward makes this suggestion explicitly as well (ibid.: 120) when she says that there is an ambiguity in the noun 'state', where we can read it in the mass or the

\footnotetext{
55 A minor point I need to make here is that Marcus (ibid.: 218ff) and Steward (ibid.: 114) attempt to argue on the basis of all this linguistic evidence that states are not particulars. Even if they are right to think this about the non-particularity of states, it is important to keep in mind that the similarities between states and mass-quantifiable stuff stops there. Quantities of stuff, such as water, are most plausibly particulars; though they are not individuals. Thanks to E. J. Lowe for emphasising this point to me in conversation. If Lowe is right, this also puts in doubt the conclusion that we should think of states as nonparticulars on this basis.
} 
count sense. ${ }^{56}$ When we are talking about count-quantifiable states of pain or desire, it seems that we are merely talking about certain occurrences or episodes of pain and desire, which we could count. For instance, 'Jonny had five pains in his stomach this morning' is intelligible. However, when we consider what the truthmakers are for such a truthbearer, the best candidates would be the various occurrences of pain that he had in his stomach this morning. But then the pains described would now better be understood as events, rather than states. We are talking about something different, or as some might say a different category of thing. Whether to give this category of thing that we are talking about an ontological reading or a modest reading is what is at issue here.

The occurrences of the pain in his stomach, as the arguments so far for the nature of events have indicated, would have a start and a finish, a spatio-temporal location, and thus be countable. Although Steward leaves open the possibility that such problematic cases may indicate that there are countable states, she also suggests that the senses in which such problematic cases allow for a count-quantifiable interpretation just indicate that the candidate states that we are talking about should not be counted as states at all. ${ }^{57}$ Whatever reading we give things it seems most plausible then that what has happened is a mere changing of subject, a change of what the truthbearers are about, and hence a change in their relevant truthmakers. However, what consequences we must draw or can plausibly draw for the nature of truthmakers is what we need to decide. The ontologists seem to think that the change of subject indicates that there must be a substantial change in the kind of entity we are talking about rather than something more modest.

Perhaps to make this change of subject matter counterargument to the objection Steward discusses more persuasive, we can see that a similar argument can be leveled against those who would change the usage and semantic-talk of the stuff that I compared states to earlier: stuff such as water or cheese. We could meaningfully say, using the mass-nouns 'water' and 'cheese':

T15: There are three different waters in my glass; I just mixed tap water with Evian and Volvic water.

T16: There are four cheeses in the refrigerator; a Brie, an Old Gouda, a Parmesan, and a Brazilian Minas.

However, when we do this, we are clearly not talking anymore about stuff. We are not counting three waters or four cheeses, as three and four particular stuffs. Instead, we are counting three kinds of water, four kinds of cheese or perhaps four blocks of cheese; we are talking about kinds and objects, which are count-quantified, and not stuffs, which are mass-quantified. Although there seems to be an ambiguity in meaning, since we can use terms such as 'water' or 'cheese' in various ways, there seems to be a clear way of using these stuff-terms in which obviously different ways

\footnotetext{
56 This is, as she (ibid.) puts it as well, the familiar sense in which we can talk about the distinction between type and token states.

57 See Steward (ibid.: 120-133) for extensive argumentation that the notion of a token state is very problematic and should be rejected. Marcus (2009) is an extended argument for this claim. What I have said here in this paragraph is my explanation of why there is a significant change of subject matter.
} 
of being are represented and talked about. When we use 'water' as a term to represent the stuff water, then the question 'How many?' does not apply. Rather, we ask, 'How much?' So, the ambiguities between the mass-noun uses and the countnoun uses of stuff are not merely grammatical, but actually refer to (or are about) different ways things are. ${ }^{58}$ This indicates a strong connection between the very subtle features of truthbearers which indicate a radical difference in aboutness, and, hence, a radical difference in the kinds of truthmakers that different truthbearers can be about and be made true by.

However, this is compatible with being completely agnostic about what is the right ontological theory of the truthmakers which make these truthbearers true and which they are strictly and fully about. In particular, there seems no reason to take the different kinds of quantification (mass- versus count-quantification) as indicating that there are entities in the metaphysically substantial sense that I've been avoiding; clearly there are differences in entities involved in the truthmakers, but they are not differences regarding which things exist, but in how what exists exists.

It seems that we can use general terms, such as 'stuff' and 'states', as count nouns, perhaps pragmatically, and to refer to the species or varieties of how things can be in the world individually. So for example, 'cheese' can be used to say, 'We have eaten a lot of cheese' and it can be used to say, 'The cheeses of France are various and go exquisitely with wine. ${ }^{59}$ In this case, as I have pointed out, we use this term ambiguously, sometimes to talk about one kind of way things can be and sometimes to talk about another way things can be. I think that this point holds for states as well as for stuff. ${ }^{60}$ Psychologists may, at some point in time, be able to map out all the varieties of different kinds of depression, and, perhaps, be able to mark out all the different kinds of mental states that persons can have. If this is so, we would be able to count all the different depressions and all the different mental states. There may be 227 different mental states and ten different kinds of depression. But, as indicated, what we are counting are the different kinds of mental states and states of depression. We are not counting particular entities (mistakenly construing mental states or depressions as particular countable events or objects). Rather, on these uses of 'state' and 'stuff' as countable terms, we are ranging over varieties or kinds of states and stuff, which are neither events, states, or stuff themselves, but are nevertheless countable. Thus again, we have changed the subject from states to kinds of states.

But, even though we might be able to make various distinctions based on linguistic evidence between kinds of states versus states, kinds of stuff versus stuff, states versus events, none of these distinctions indicate any distinctions in anything

\footnotetext{
58 There is no need to claim that they are different things over and above the ways things are.

59 Chappell (1970-1971: 62) also highlights this point.

60 This sort of ambiguity is related to the semantic phenomenon of type-shifting. These sorts of category shifts often occur without our notice and even within a sentence, such as in cases of zeugma [e.g. 'The number is large and rising' and 'Miss Bolo went straight home, in a flood of tears and a sedan-chair' (Ryle 1949: 11; Dickens 1837: Chapter 35)]. See also Pietroski’s (2005: especially $\S \S 3$ and 4.2) discussion of lexical flexibility and ontology. I thank an anonymous reviewer for suggesting this.
} 
ontologically significant or metaphysically substantial. There is no reason to think, based on the linguistic evidence exhibited in the various arguments I have presented, that they are further metaphysically substantial entities that need to play the truthmaker-role. Rather, we can construe them fundamentally or metaphysically in all sorts of different ways, for instance as merely aspects of things, being-in-thewider sense of containing how things are with entities (recall also the various ways of construing the potential truthmakers in especially $\$ 1.1$, including Lewis's). At the very least, there is no good reason to assume that we can know, merely on the basis of the semantics of truthbearers, whether what we are talking about is ontologically substantial. ${ }^{61}$ It seems much more likely that questions concerning the fundamental metaphysical nature of whatever we are talking about will be decided, if at all, by metaphysical argumentation rather than argumentation based on truthmaker theory and language.

\subsection{Modesty and reality}

Before ending and also to sum up, I'd like to address two general questions about the non-ontological approach which I have defended in this paper in part by criticising an ontological approach to truthmaking. I have so far argued that facts about, for instance, grammatical aspect that are taken by some to reveal an ontological distinction between events and states really speak to and are more modestly explained by a non-ontological distinction between ways for matters to stand. First, one might ask what exactly has been the target? Can something general be said about the target so that the non-ontological and the ontological approaches can be properly distinguished? And second, what are some positive things to say about the non-ontological approach—what might it consist in? It might so far still be hard to see what the non-ontological approach comes to in particular cases. Sometimes we might be dealing with two linguistically different ways of getting at the same facts, e.g. 'I won' vs 'I have won', or active and passive cognates. Other times there seems to be a non-ontological but still not merely linguistic distinction between ways things can be, for instance stative vs eventive. To evaluate the critique of ontological approaches we need to see the non-ontological alternative or alternatives laid out. ${ }^{62}$

First, the main target of the paper has been what we might call "an ontological approach to truthmakers" on which SOAs are entities with a structure generally isomorphic with the structure of the truthbearers which they are supposed to make true (this structural isomorphism might come in two forms: (a) the SOA having a complex internal structure corresponding to, for instance, the subject-predicate structure of the truthbearers, as would be the case with Russellian SOAs, or (b) the SOA being basic but also such that we can abstract elements out of it, such as the objects and the properties, which correspond to the elements such as subjects and

\footnotetext{
61 In addition, Dodd (1999), as I've pointed out several times, gives us strong metaphysically salient reasons for rejecting SOAs and all of these presumably complex entities as entities in their own right.

62 I thank an anonymous reviewer for raising these issues.
} 
predicates which we can abstract from a truthbearer, which in turn is the more basic linguistic unit). The alternative, modest approach which uses EAT rather than NEC has no commitment to a structural isomorphism between truthbearers and truthmakers and is wholly compatible with what Austin says when he writes:

There is no need whatsoever for the words used in making a true statement to 'mirror' in any way, however indirect, any feature whatsoever of the situation or event; a statement no more needs, in order to be true, to reproduce the 'multiplicity', say, or the 'structure' or 'form' of the reality, than a word needs to be echoic or writing pictographic. To suppose that it does, is to fall once again into the error of reading back into the world the features of language.

[1979: 124, 125]

In fact, there need not be a general non-ontological alternative which can tell us exactly what the difference is between, for instance, states and events-that is, which can tell us what the difference is between the nature of states and events. Saying what exactly the difference is between them would be succumbing to the temptation of the ontologist who feels the need to explain the difference at the level of entities. This may be possible on metaphysical grounds, but it seems that nothing about the truthbearers, as linguistic items, can give us the answer.

What we require and what EAT allows is a piecemeal approach. In the case of active vs passive ways of getting at the same facts, the distinction is clearly purely linguistic. This is captured in terms of EAT by the fact that truthbearers expressed in the active vs in the passive are exactly about the same things and how things are with those things - any difference between the two doesn't demand any worldly difference in potential truthmakers.

However, some distinctions are indeed not merely linguistic but also not ontological and concern ways things can be, e.g. the stative vs eventive. The reason for the focus on states and events in this paper is that the common move is to take the distinction to be ontological, on what are best understood as necessitarian truthmaker grounds. Hence, this is why the distinction between states and events is particularly interesting as an illustration of the non-ontological approach to truthmakers and aboutness.

Second, there is also something more general to say about the non-ontological alternative. What I would like to do is to introduce a modest reality principle or reality operator. This is similar to but isn't the same as what Cameron (2010) introduces: a special kind of quantifier to indicate what really exists. What I would like to say is compatible with this, insofar as it doesn't interpret the quantifier or operator as a sort of fundamentality operator which stratifies layers of reality (this is perhaps metaphysically substantial and potentially immodest in different ways than the ways I am criticising in this paper). The operator has a wider application, for it is non-ontological and completely in tune with the normal use of 'really', 63 and thus also in these senses metaphysically modest. Instead of using the operator to say that

\footnotetext{
63 For the ordinary sense of 'real', which is contrasted with 'illusory' rather than 'merely existing', see Austin (1962: 62-77), Ayer (1936: 10), and Twardowski (1927).
} 
something really exists, we should talk about things really being red or really walking across the street. This doesn't mean that there is a type of being red or walking across the street which is more fundamental than others. Using 'really' indicates that matters are really that way, rather than that it was an illusion or a hallucination or in some other way not really how things are. The metaphysically modest and non-ontological approach to truthmakers and aboutness can be nicely captured with such an operator and the following reality principle:

Aboutness Realism (AR): If those parts (or aspects) of reality $x, x_{1}, x_{2}, \ldots, x_{n}$ which a truthbearer $p$ is exactly about make $p$ true, then $x, x_{1}, x_{2}, \ldots, x_{n}$ are real and are really the way they are described.

The point of talking about truthmakers at all is at the very least to express the idea that a difference in truth value requires a difference in reality. The important point I'm arguing for in this paper is that such a difference in reality need not be an ontological difference, a difference in what exists. Thus, for instance, the difference in the truthmakers for stative truthbearers and eventive truthbearers need not involve a difference in entities at all: it might only require a difference in how things are with entities (e.g. an entity might be some way that we can describe as its being in some state, for instance its being red, or it might be some way, for instance doing something such as running up a flight of stairs, which we can describe as its undergoing a process or performing an event. None of these have to be a separate further entity). At the very least it requires a difference in reality, whatever the difference is. To find this out we would require first and most importantly to look at what the specific truthbearer we are considering is exactly about; and what a truthbearer is exactly about will vary from case to case: sometimes it's about a stative way things are, sometimes an eventive way, and sometimes perhaps some other way. Pietroski captures the point here well when clarifying his non-ontological approach to France:

We can speak quasi-commonsensically of France being a "truth-maker" for (I), ( $\mathrm{I} a)$, ( $\mathrm{I} b)$, and $(\mathrm{I} c)$. But it doesn't follow that France is an entity that satisfies the predicates in these sentences, at least not if 'satisfies' is used in its standard technical sense, derived from Frege $(1879,1892)$ and Tarski (1933). This does not challenge the commonsense claim that France is a perfectly real country that one can visit. [2005: 276, 277]

To sum up, what we want for truthmakers isn't always existence but a perfectly ordinary and non-ontological sense of reality.

\section{Conclusion}

Overall, in this paper, I introduced and defended the notion of metaphysical modesty which comes with an aboutness-based version of truthmaker theory. I illustrated this account by explaining how one can see the linguistically-based debate concerning the distinction between supposedly different ontological 
categories, especially that between states and events on the basis of aspect, in a metaphysically modest way.

Acknowledgements Special thanks are due to Paul Snowdon for his constant support, encouragement, and his many very helpful comments on this paper. I would also like to thank Guy Longworth, E. J. Lowe, Jennifer Hornsby, Julian Dodd, R. V. Schipper, and Stacie Friend for reading some earlier and some later drafts and for providing helpful comments. Also, Tim Crane has been constantly very encouraging, generally and about this paper in its early form. E. J. Lowe's comments especially pressed me to think hard about the view of truth that underlies the strategy of drawing ontological conclusions from linguistic data. I thank Peter Unger for his encouragement and for directly inspiring me in my thinking in this paper, especially on matters of ontological substance and the nature of states and events. Finally, I want to thank an anonymous reviewer for very helpful comments.

Open Access This article is distributed under the terms of the Creative Commons Attribution 4.0 International License (http://creativecommons.org/licenses/by/4.0/), which permits unrestricted use, distribution, and reproduction in any medium, provided you give appropriate credit to the original author(s) and the source, provide a link to the Creative Commons license, and indicate if changes were made.

\section{References}

Ayer, A. J. (1936). Language, truth and logic. London: Victor Gollancz Ltd.

Armstrong, D. M. (1997). A world of states of affairs. Cambridge: Cambridge University Press.

Armstrong, D. M. (2003). Truthmakers for modal truths. In H. Lillehammer \& G. Rodriguez-Pereyra (Eds.), Real metaphysics: Essays in honour of D. H. Mellor (pp. 12-24). London: Routledge.

Armstrong, D. M. (2004). Truth and truthmakers. Cambridge: Cambridge University Press.

Austin, J. L. (1962). Sense and Sensibilia. Oxford: Oxford University Press.

Austin, J. L. (1979). Truth. In J. O. Urmson \& G. J. Warnock (Eds.), Philosophical papers (3rd ed.) (pp. 117-133). Oxford: Oxford University Press.

Barwise, J. (1989). The situation in logic. Stanford: CSLI.

Barwise, J., \& Perry, J. (1983). Situations and attitudes. Cambridge, MA: MIT Press.

Beaney, M. (2017). Analytic philosophy. Oxford: Oxford University Press.

Bennett, J. (1988). Events and their names. Oxford: Clarendon Press.

Bennett, K. (2011). Truthmaking and case-making. Philosophy and Phenomenological Research, 83(1), 187-195.

Bennett, K., \& McLaughlin, B. (2014). Supervenience. In E. N. Zalta (Ed.), Stanford encyclopedia of philosophy (Spring 2014 Edition). Retrieved July 20, 2016, from http://plato.stanford.edu/archives/ spr2014/entries/supervenience/.

Bigelow, J. (1988). The reality of numbers: A physicalist's philosophy of mathematics. Oxford: Clarendon Press.

Cameron, R. (2010). Quantification, naturalness and ontology. In A. Hazlett (Ed.), New waves in metaphysics (pp. 8-26). Basingstoke: Palgrave MacMillan.

Chappell, V. C. (1970-1971). Stuff and things. Proceedings of the Aristotelian Society, 71, 61-76.

Crane, T. (2001). Elements of mind: An introduction to the philosophy of mind. Oxford: Oxford University Press.

Crane, T. (2013). The objects of thought. Oxford: Oxford University Press.

Davidson, D. (1969). The individuation of events. In D. Davidson (Ed.), (1980) Essays on actions and events (pp. 163-180). Oxford: Clarendon Press.

Dickens, C. (1837). The posthumous papers of the Pickwick Club. London: Chapman and Hall.

Dodd, J. (1999). Farewell to states of affairs. Australasian Journal of Philosophy, 77, 146-160.

Dodd, J. (2000). The identity theory of truth. New York: Palgrave MacMillan.

Dodd, J. (2002). Is truth supervenient on being? Proceedings of the Aristotelian Society, 102, 69-86.

Dodd, J. (2007). Negative truths and truthmaker principles. Synthese, 156, 383-401. 
Dodd, J. (2009). Events, facts and states of affairs. In R. Cameron, et al. (Eds.), The Routledge companion to metaphysics (pp. 322-334). London and New York: Routledge, Taylor \& Francis Group.

Fine, K. (1982). First-order modal theories III-Facts. Synthese, 53, 43-122.

Fine, K. (2012). Guide to ground. In F. Correia \& B. Schnieder (Eds.), Metaphysical grounding (pp. 37-80). Cambridge: Cambridge University Press.

Fine, K. (2015). Yablo on subject-matter. Unpublished manuscript, citable draft version, https://www. academia.edu/15555407/Review_of_Steve_Yablos_Aboutness. Accessed August, 2015.

Fine, K. (2017). Truthmaker semantics. In B. Hale, A. Miller, \& C. Wright (Eds.), A companion to the philosophy of language (pp. 556-577). London: Wiley.

Forbes, G. (1989). Languages of possibility. Oxford: Basil Blackwell.

Fox, J. (1987). Truthmaker. Australasian Journal of Philosophy, 65(2), 188-207.

Frege, G. (1879). Begriffsschrift. Halle: Verlag von Louis Nebert.

Frege, G. (1892). Function and concept. In P. Geach \& M. Black (tr.) (1980) Translations from the philosophical writings of Gottlob Frege. Oxford: Blackwell.

Galton, A. (1984). The logic of aspect. Oxford: Oxford University Press.

Galton, A. (2006). On what goes on: The ontology of processes and events. In B. Bennett \& C. Fellbaum (Eds.), Formal ontology in information systems: Proceedings of the Fourth International Conference (FOIS2006) (pp. 4-11). Amsterdam: IOS Press.

Galton, A. (2012a). The ontology of states, processes, and events. InterOntology February 23, 2012, February 24, 2012 (Vol. 5, pp. 35-45). Keio University, Tokyo, Japan (11).

Galton, A. (2012b). States, processes and events, and the ontology of causal relations. In M. Donnelly \& G. Guizzardi (Eds.), Formal ontology in information systems (pp. 279-292). Amsterdam: IOS Press.

Gendler-Szabo, Z. (2004). On the progressive and perfective. Noûs, 38(1), 29-59.

Gill, K. (1993). On the metaphysical distinction between processes and events. Canadian Journal of Philosophy, 23(3), 365-384.

Goodman, N. (1961). About. Mind, 70(277), 1-24.

Horgan, T. (1993). From supervenience to superdupervenience: Meeting the demands of a material world. Mind, 102(408), 555-586.

Hossack, K. (2007). The metaphysics of knowledge. Oxford: Oxford University Press.

Huemer, M. (2009). When is parsimony a virtue? Philosophical Quarterly, 59, 216-236.

Kenny, A. (1963). Action, emotion and will. London: Routledge.

Kim, J. (1966). On the psycho-physical identity theory. American Philosophical Quarterly, 3, $277-285$.

Kim, J. (1976). Events as property exemplifications. In M. Brand \& D. Walton (Eds.), Action theory (pp. 159-177), Dordrecht: Reidel; Reprinted in Kim (1993) Supervenience and mind: Selected philosophical essays (pp. 33-52). Cambridge: Cambridge University Press.

Kriegel, U. (2013). The epistemological challenge of revisionary metaphysics. Philosophers' Imprint, 13(12), 1-30.

Leech, G. N. (1969). Towards a semantic description of english. Bloomington: Indiana University Press.

Lemmon, J. (1967). Comments on D. Davidson's The logical form of action sentences. In N. Rescher (Ed.), The logic of decision and actions (pp. 96-103). Pittsburgh: The University of Pittsburgh Press.

Lewis, D. K. (1988). Statements partly about observation. Philosophical Papers, 17(1), 1-31.

Lewis, D. K. (1992). Critical notice of D.M. Armstrong's a combinatorial theory of possibility. Australasian Journal of Philosophy, 70(2), 211-224.

Lewis, D. K. (2003). Things qua truthmakers. In H. Lillehammer \& G. Rodriguez-Pereyra (Eds.), Real metaphysics: Essays in honor of D. H. Mellor (pp. 25-38). London: Routledge.

Lewis, D. K., \& Rosen, G. (2003). Postscript to 'Things qua truthmakers': Negative existentials. In H. Lillehammer \& G. Rodriguez-Pereyra (Eds.), Real metaphysics: Essays in honour of D. H. Mellor (pp. 39-42). London: Routledge.

MacBride, F. (2005). Lewis's animadversions on the truthmaker principle. In H. Beebee \& J. Dodd (Eds.), Truthmakers: The contemporary debate (pp. 117-140). Oxford: Oxford University Press.

Marcus, E. (2009). Why there are no token states. The Journal of Philosophical Research, 34, $215-231$.

Mellor, D. H. (1995). The facts of causation. London and New York: Routledge.

Mellor, D. H. (2003). Real metaphysics: Replies. In H. Lillehammer \& G. Rodriguez-Pereyra (Eds.), Real metaphysics: Essays in honour of D.H. Mellor (pp. 212-238). London: Routledge.

Merricks, T. (2007). Truth and ontology. Oxford: Clarendon Press.

Molnar, G. (2000). Truthmakers for negative truths. Australasian Journal of Philosophy, 78(1), 72-86.

Mourelatos, A. P. D. (1978). Events, processes, and states. Linguistics and Philosophy, 2, 415-434. 
Mulligan, K., Smith, B., \& Simons, P. (1984). Truth-makers. Philosophy and Phenomenological Research, 44(3), 287-321.

Parsons, T. (1985). Underlying events in the logical analysis of english. In E. LePore \& B. McLaughlin (Eds.), Actions and events: Perspectives on the philosophy of Donald Davidson (pp. 235-267). Oxford: Blackwell.

Paul, L. A. (2012). Metaphysics as modeling: The handmaiden's tale. Philosophical Studies, 160, 1-29.

Pietroski, P. (2005). Meaning before truth. In G. Preyer \& G. Peter (Eds.), Contextualism in philosophy: Knowledge, meaning, and truth (pp. 255-302). Oxford: Clarendon Press.

Prior, A. N. (1971). Objects of thought. Oxford: Oxford University Press.

Putnam, H. (1958). Formalization of the concept 'About'. Philosophy of Science, 25, 125-130.

Quine, W. V. O. (1948). On what there is. The Review of Metaphysics, 2(5), 21-38. Reprinted in (1953) From a Logical Point of View (pp. 1-19). Cambridge, MA: Harvard University Press.

Quine, W. V. O. (1985). Events and reification. In E. LePore \& B. McLaughlin (Eds.), Actions and events: Perspectives in the philosophy of Donald Davidson (pp. 162-171). Oxford: Blackwell.

Rayo, A., \& Yablo, S. (2001). Nominalism through de-nominalisation. Nô̂s, 35, 74-92.

Rodriguez-Pereyra, G. (2005). Why truthmakers? In H. Beebee \& J. Dodd (Eds.), Truthmakers: The contemporary debate (pp. 17-31). Oxford: Oxford University Press.

Rosefeldt, T. (2008). 'That'-clauses and non-nominal quantification. Philosophical Studies, 137, 301-333.

Russell, B. A. W. (1985). The philosophy of logical atomism (1918). In D. Pears (Ed.), The philosophy of logical atomism (pp. 35-157). Chicago and La Salle, Illinois: Open Court Publishing.

Ryle, G. (1933). About. Analysis, 1, 10-11.

Ryle, G. (1949). The concept of mind. London: William Brendon and Son Ltd.

Smith, B. (1999). Truthmaker realism. Australasian Journal of Philosophy, 77, 274-291.

Steward, H. (1997). The ontology of mind: Events, states, and processes. Oxford: Clarendon Press.

Tarski, A. (1933). The concept of truth in formalized languages. Reprinted in Tarski (1983) Logic, semantics, metamathematics, J. H. Woodger (tr.), (2nd edn.) J. Corcoran (Ed.), Indianapolis: Hackett.

Textor, M. (2016). States of affairs. In E. N. Zalta (Ed.), The Stanford encyclopedia of Philosophy (Winter 2016 Edition), https://plato.stanford.edu/archives/win2016/entries/states-of-affairs/. Accessed 5 Aug 2018.

Twardowski, K. (1927). On the logic of adjectives. In J. Brandl \& J. Woleński (Eds.), Twardowski (1999) On actions, products and other topics in philosophy (pp. 141-146). Amsterdam: Rodopi.

Vendler, Z. (1957). Verbs and times. Philosophical Review, 66, 143-160.

Westerhoff, J. (2005). Ontological categories: Their nature and significance. Oxford: Clarendon Press.

Willard, M. B. (2014). Against simplicity. Philosophical Studies, 167, 165-181.

Williamson, T. (2003). Everything. Philosophical Perspectives, 17, 415-465.

Wright, C. (2007). On quantifying into predicate position: Steps towards a new(tralist) perspective. In M. Leng, A. Paseau, \& M. Potter (Eds.), Mathematical knowledge (pp. 150-174). Oxford: Oxford University Press.

Yablo, S. (1996). How in the world. Philosophical Topics, 24(1), 255-286.

Yablo, S. (2014). Aboutness. Princeton, NJ: Princeton University Press. 